\title{
PERILAKU MAKAN DAN KESEJAHTERAAN SUBJEKTIF MAHASISWA
}

\section{EATING BEHAVIOR AND SUBJECTIVE WELFARE OF STUDENTS}

\author{
Nina Fitriana \\ Universitas Mercu Buana Yogyakarta \\ nina@mercubuana-yogya.ac.id
}

\begin{abstract}
Abstrak
Mahasiswa memiliki beragam tanggung jawab baik secara akademis maupun non akademis yang harus dijalani. Kesuksesan menjalankan berbagai peran tersebut sangat dipengaruhi oleh bagaimana ia dapat menikmati dan merasa bahagia dengan proses yang dijalani. Kebahagiaan atau sering diistilahkan dengan subjective well being menjadi salah satu hal yang sangat mempengaruhi kesuksesan mahasiswa dalam menjalani kehidupannya. Terdapat beberapa faktor yang dapat mempengaruhi subjective well being, diantaranya adalah perilaku makan. Dengan demikian, penelitian ini bertujuan untuk melihat apakah terdapat hubungan perilaku makan dengan subjective well being. Sehingga hipotesis penelitian ini adalah terdapat hubungan positif antara perilaku makan dan subjective well being. Jumlah subjek dalam penelitian ini adalah 65 mahasiswa. Metode pengumpulan data menggunakan skala Subjective Well Being dan Eating Habit Questionnaire. Skala Subjective Well Being terdiri dari 3 sub skala, yaitu Satisfaction With Life Scale dengan 5 aitem, Positive Affect dengan 9 aitem, dan Negative Affect dengan 9 aitem. Sedangkan skala Eating Habit Questionnaire terdiri dari 21 aitem. Teknik analisis korelasi product moment digunakan untuk mengetahui hubungan tersebut. Hasil penelitian dinyatakan bahwa tidak ada hubungan antara perilaku makan dengan subjective well being.
\end{abstract}

Kata Kunci: subjective well being, perilaku makan, mahasiswa

\begin{abstract}
Students have a variety of responsibilities both academically and non-academically which must be undertaken. The success of carrying out these various roles is greatly influenced by how they can enjoy and feel happy with the process that is being undertaken. Happiness or often termed as subjective well being is one of the things that greatly affect the success of students in living their lives. There are several factors that can influence subjective well being, including eating behavior. Thus, this study aims to see whether there is a relationship between eating behavior and subjective well being. Therefore, the hypothesis of this study is that there is a positive relationship between eating behavior and subjective well being. The number of subjects in this study was 65 students. The method of data collecting conducted the Subjective Well Being scale and Eating Habit Questionnaire. The Subjective Well Being Scale consists of 3 sub-scales, namely Satisfaction with Life Scale with 5 items, Positive Affect with 9 items, and Negative Affect with 9 items. While the scale of the Eating Habit Questionnaire consists of 21 items. Product moment correlation analysis technique is used to find out the relationship. The results of the study stated that there was no relationship between eating behavior with subjective well being.
\end{abstract}

Keywords: subjective well being, eating behavior, students

\section{PENDAHULUAN}

Sepanjang sejarah, mahasiswa di berbagai negara memiliki peran penting dalam sejarah suatu bangsa. Hal ini sejalan dengan pendapat Muhibullah (2011) yang menyatakan bahwa mahasiswa memiliki tugas dan tanggungjawab yang cukup besar baik sebagai individu maupun sebagai bagian dari warga negara. Mahasiswa dapat berupa agen perubahan, kontrol sosial, dan juga generasi penerus bangsa. 
Namun, peran dan tanggungjawab mahasiswa sekarang ini telah mengalami kemunduran (Muhibullah, 2011). Mundurnya peran dan tanggungjawab serta menurunnya kualitas mahasiswa terkait dengan beberapa masalah yang dihadapi mahasiswa (Sudjarwadi, 2003). Permasalahan yang dialami mahasiswa dapat terkait dengan proses belajar ataupun di luar proses belajar tersebut.

Permasalahan yang terkait dengan proses belajar diantaranya adalah cukup tingginya tingkat keterlambatan mahasiswa dalam mengikuti perkuliahan di kelas. Permasalahan ini sangat terkait dengan pengaturan waktu yang dimiliki mahasiswa. Selain itu, permasalahan yang juga muncul terkait dengan proses belajar adalah kemampuan mahasiswa untuk dapat fokus dalam mengikuti pelajaran termasuk kemampuan mahasiswa dalam mengerjakan tugas mata kuliah. Mahasiswa juga menghadapi permasalahan terkait dengan metode pembelajaran yang diberikan di kampus (Prasetiyo \& Andriani, 2011). Sedangkan permasalahan yang muncul di luar proses belajar misalnya terkait dengan pergaulan dengan teman sebaya, pengaturan keuangan, maupun permasalahan dengan keluarga Qonitatin (2009).

Tuntutan tanggungjawab yang dipikul mahasiswa dapat menjadi tekanan yang dapat mempengaruhi kondisi psikologisnya. Permasalahan-permasalahan yang dihadapi mahasiswa dapat menimbulkan tingginya afek negatif, rendahnya afek positif, dan rendahnya kepuasan hidup. Dengan kata lain, permasalahan yang dialami mahasiswa dapat menimbulkan rendahnya subjective well being (Qonitatin, 2009).

Diener (2000) menyatakan bahwa subjective well being merupakan penilaian terhadap kehidupan individu baik secara kognitif maupun afektif. Evaluasi yang bersifat kognitif mencakup bagaimana seseorang merasakan kepuasan dalam hidupnya, sedangkan evaluasi afektif mencakup seberapa sering seseorang mengalami afek negatif dan afek positif. Hal ini sesuai dengan pendapat Tellegen (1996) bahwa afek positif yang tinggi terjadi ketika individu merasakan energi yang tinggi, konsentrasi penuh, dan keterlibatan pada suatu aktifitas yang menyenangkan.

Subjective well being berkaitan dengan afek menyenangkan, afek yang kurang menyenangkan serta kepuasan hidup. Hal ini sejalan dengan pernyataan Cha (2003) yang menyatkan bahwa subjective well being ditentukan oleh tiga aspek berbeda namun saling berhubungan yaitu adanya afek positif, tidak adanya afek negatif, dan adanya kepuasan hidup. Kepuasan hidup merupakan bentuk kemampuan seseorang untuk menikmati pengalaman disertai dengan kegembiraan. Penilaian kepuasan didasarkan pada perbandingan antara kondisi diri dengan standar yang ada yang mencakup orang lain, masa lalu, tingkat aspirasi dan ide dari kepuasan, serta kebutuhan atau tujuan lain (Diener dalam Putri dan Sutarmanto, 2008).

Ariati (2010) menyatakan bahwa subjective well being dapat diketahui dari ada atau tidaknya perasaan bahagia. Selain itu, Ehrlich dan Isaacowitz (2002) menyatakan bahwa subjective well being adalah ukuran seberapa baik keadaan individu dalam waktu tertentu. Subjective well being juga dapat didefinisikan sebagai sebuah konsep multidimensional yang mencakup moral, kepuasan 
hidup, kepuasan di bidang tertentu, perbedaan antara afek positif dan negatif seseorang (Tran van Thanh, 1986).

Menurut Diener (2000) terdapat tiga aspek subjective well being, yaitu kepuasan hidup, afek negatif, dan afek positif. Selain pendapat Diener, Haybron dalam Eid dan Larsen (2008) mengungkapkan satu aspek tambahan selain tiga aspek yang disampaikan oleh Diener di atas. Aspek tersebut adalah domain kepuasan. Pada budaya barat, kepuasan hidup didefinisikan sebagai otonomi dan perasaan penuh dengan kebermaknaan serta pertumbuhan (Haybron dalam Eid dan Larsen, 2008). Kepuasan hidup merupakan hal yang amat penting dalam kehidupan seseorang. Pada negara tertentu, mahasiswa merasa uang lebih penting dibandingkan dengan kebahagiaan dan kepuasan hidup. Namun, di kebanyakan negara, mahasiswa merasa hal yang sebaliknya, yaitu kepuasan hidup dan kebahagiaan merupakan hal yang paling utama.

Agar mahasiswa dapat mengatasi permasalahannya dan dapat menjalani peran dan tanggungjawab dengan baik, mahasiswa diharapkan memiliki tingkat subjective well being yang tinggi (Sudjarwadi, 2003). Mahasiswa dengan tingkat subjective well being yang tinggi akan memiliki kinerja yang baik di bidang akademis. Selain itu, dengan tingkat subjective well being yang tinggi mahasiswa juga mampu menjadi pemimpin yang baik di masa yang akan datang.

Kebahagiaan merupakan bagian dari subjective well being (Diener, 2000). Orang yang bahagia akan lebih berhasil di sepanjang rentang kehidupannya. Selain itu, individu tersebut akan lebih mudah mencapai situasi dan kondisi kehidupan yang lebih menyenangkan (Diener, 2003). Orang yang bahagia akan sering mengalami suasana hati yang positif yang akan menggugah seseorang untuk bekerja lebih aktif untuk mencapai tujuan yang baru serta sumber daya yang baru. Dengan bekerja aktif seseorang akan cenderung lebih mudah mendapatkan kesuksesan. Hal ini sejalan dengan pendapat Larsen \& Eid (2008) yang menyatakan bahwa kebahagiaan merupakan penyebab potensial seseorang untuk sukses (Eid dan Larsen, 2008). Kebahagiaan merupakan salah satu aspek dari subjective well being. Dengan demikian dapat disimpulkan bahwa individu yang bahagia dan memiliki tingkat subjective well being yang tinggi diharapkan dapat sukses dalam kehidupan.

Orang yang bahagia akan cenderung lebih aktif dalam mencapai tujuan hidup. Hal ini akan berdampak pada lebih mudahnya seseorang dalam mencapai kesuksesan. Sesuai dengan pendapat Diener (2008) bahwa seseorang yang bahagia akan cenderung lebih mudah sukses dibandingkan dengan yang tidak bahagia. Individu yang bahagia akan memiliki harga diri positif. Ia akan mampu mengontrol lingkungan, memiliki rasa optimis, memiliki hubungan sosial yang positif, dan rasa kebermaknaan serta tujuan hidup yang jelas. Selain itu, ia akan memiliki resolusi konflik internal (Argyle, Myers, Diener dalam Wirawan, 2010). Kebahagiaan juga mendorong tercapainya sebuah kesuksesan dalam pekerjaan, hubungan, dan kesehatan. Kesuksesan tersebut merupakan bagian dari pengaruh positif seseorang (Wirawan, 2010). Individu dengan subjective well being yang 
tinggi akan merasa lebih percaya diri, dapat menjalin hubungan sosial dengan baik, serta melakukan performansi kerja yang baik (Utami, 2009).

Terdapat beberapa faktor yang mempengaruhi subjective well being seseorang, diantaranya kepribadian, tujuan hidup, kemampuan beradaptasi dan coping, kesehatan, pendapatan, agama, pernikahan, usia, perbedaan jenis kelamin, job morale, pendidikan, dan kecerdasan (Diener, dkk, 2008). Faktor lain yang mempengaruhi tingkat subjective well being seseorang adalah perilaku makan (Fluglestad dkk, 2013).

Perilaku makan merupakan tindakan seseorang terhadap makanan yang dipengaruhi oleh persepsi dan pengetahuan terhadap makanan (Gibney, dkk, 2008). Menurut Koentjaraningrat (dalam Khumaidi, 1994), perilaku makan adalah cara seseorang berpikir atau berpengetahuan, berperasaan, dan perpandangan, tentang makan. Sdangkan menurut Guthe \& Mead (dalam Khumaidi,1994) perilaku makan adalah cara-cara individu dan kelompok individu memilih, mengkonsumsi dan menggunakan makanan-makanan yang tersedia, yang didasarkan kepada faktor- faktor sosial dan budaya dimana individu hidup. Berdasarkan beberapa pengertian di atas, dapat disimpulkan bahwa perilaku makan adalah tingkah laku manusia atau sekelompok manusia dalam memenuhi kebutuhan akan makanan yang meliputi sikap, kepercayaan, dan pilihan makanan.

Perilaku makan terkait dengan tingkat subjective well being seseorang. Penelitian yang dilakukan oleh Fluglestad (2013) menyatakan bahwa terdapat hubungan antara perilaku makan terkait dengan tingkat subjective well being seseorang. Seseorang yang tidak peduli dengan perilaku makan sehat akan memiliki tingkat well being yang rendah. Selain itu, seseorang yang tidak peduli dengan perilaku makan yang sehat juga akan memiliki perilaku makan yang tidak sehat.

Perilaku ini menyangkut mengonsumsi buah dalam jumlah sedikit, mengonsumsi makanan yang lebih banyak mengandung gula dalam satu hari. Selain itu, mereka juga mengonsumsi lebih banyak kudapan setiap hari (Fluglestad, 2013). Selain itu, penelitian ini juga menyatakan bahwa dewasa muda yang memiliki perilaku makan yang tidak konsisten akan memiliki psychological well being yang rendah dan secara umum memiliki perilaku makan yang tidak sehat dibandingkan dengan orang yang memiliki perilaku makan yang konsisten.

Berdasarkan latar belakang yang telah dipaparkan di atas, peneliti tertarik untuk melakukan penelitian mengenai hubungan perilaku makan dengan tingkat subjective well being mahasiswa sehingga dapat dirumuskan bahwa apakah terdapat hubungan antara perilaku makan dengan tingkat subjective well being pada mahasiswa? Tujuan penelitian ini adalah untuk mengetahui terdapat hubungan antara perilaku makan dengan tingkat subjective well being mahasiswa.

\section{METODE}

Penelitian ini merupakan penelitian kuantitatif. Terdapat dua variabel yang dikaji dalam 
penelitian ini, yaitu subjective well being sebagai variabel tergantung dan perilaku makan sebagai variabel bebas. Subjek dalam penelitian ini adalah mahasiswa sebanyak 65 orang. Teknik pengambilan data menggunakan Eating Habit Questionnaire dan skala Subjective Well Being.

Aspek dari subjective well being adalah kepuasan hidup, afek positif, dan afek negatif. Subjective well being dalam penelitian ini diukur dengan menggunakan skala Satisfaction With Life Scale modifikasi dari Diener, Emmons, Larsen, dan Griffin (1985) dan skala PANAS (Positive And Negative Effect Schedule) modifikasi dari Watson, Clark, dan Tellegen (1988). Semakin tinggi skor subjective well being mahasiswa, maka semakin tinggi tingkat subjective well beingnya, demikian pula sebaliknya, semakin rendah skor subjective well being mahasiswa, maka semakin rendah tingkat subjective well beingnya.

Subjective well being terdiri dari dimensi afektif dan dimensi kognitif atau dengan kata lain subjective well being terdiri dari afek positif, afek negatif, dan keseimbangannya dengan kepuasan hidup. Berdasarkan pernyataan di atas, dapat diformulasikan bahwa subjective well being adalah kepuasan hidup ditambah dengan afek positif dikurangi dengan afek negatif atau SWB $=$ SWLS +( $\mathrm{PA}-\mathrm{NA})$.

Perilaku makan diukur dengan menggunakan Eating Habit Questionnaire yang terdiri dari 3 aspek yaitu knowledge, problems, dan feelings. Masing-masing aspek terdiri dari 7 aitem sehingga Eating Habit Questionnaire memiliki 21 aitem. Semakin tinggi skor Eating Habit Questionnaire maka semakin baik perilaku makan yang dimiliki subjek, sebaliknya semakin rendah skor Eating Habit Questionnaire maka semakin buruk perilaku makan yang dimiliki subjek.

\section{HASIL DAN PEMBAHASAN}

Uji hipotesis dilakukan untuk mengetahui hubungan perilaku makan dengan subjective well being. Kaidah yang digunakan pada uji hipotesis ini adalah apabila diperoleh signifikansi $\mathrm{p}<$ 0,05 berarti ada korelasi antara variabel bebas dengan variabel terikat. Apabila nilai signifikansi diperoleh $p>0,05$ berarti tidak ada korelasi antara nilai variabel bebas dan variabel terikat.

Berdasarkan hasil uji hipotesis dengan analisis korelasi product moment dari Pearson antara variabel perilaku makan dan subjective well being diperoleh koefisien korelasi sebesar 0,130 dengan nilai signifikansi $0,151(\mathrm{p}>0,05)$. Hal itu menunjukkan tidak ada hubungan antara variabel bebas dengan variabel terikat. Dengan demikian dapat dikatakan bahwa tidak ada hubungan antara perilaku makan dengan subjective well being.

Subjective well being menjadi salah satu prediktor kesuksesan seseorang (Diener, 2003). Orang yang bahagia akan lebih bersemangat dalam menjalankan hidupnya. Terdapat beberapa faktor yang mempengaruhi tingkat subjective well being seseorang, kepribadian, tujuan hidup, kemampuan beradaptasi dan coping, kesehatan, agama, pendidikan, pernikahan, usia, penghasilan, perbedaan jenis kelamin, job morale, dan kecerdasan.

Seseorang dengan tingkat kesehatan yang baik memiliki tingkat subjective well being yang 
tinggi (Hoorn, 2007). Wilson dalam Diener dkk (1999) menyatakan bahwa kesehatan sangat berkorelasi dengan subjective well being. Namun, kesehatan tidak hanya dipengaruhi oleh perilaku makan. Terdapat beberapa faktor yang justru lebih berpengaruh yaitu pola pikiran, emosi, dan pola perilaku. Atkinson, dll (1998) menyatakan bahwa kepribadian merupakan bentuk pola pikiran, emosi, dan perilaku yang berbeda dan merupakan karakteristik yang menentukan gaya personal individu dan mempengaruhi interaksinya dengan lingkungan. Jiang (2010) juga menyatakan bahwa salah satu hal yang berpengaruh terhadap tingkat subjective well being seseorang adalah kepribadian. Dengan demikian hal ini menjadi salah satu alasan mengapa perilaku makan tidak mempengaruhi tingkat subjective well being. Selain dipengaruhi oleh pola makan, kesehatan juga dipengaruhi oleh faktor yang lain seperti berolahraga teratur, menjaga kesehatan pribadi, dan mengatur istirahat (Suharjana, 2012).

Selain itu, Park (dalam Nisfiannor dkk, 2004) menyatakan bahwa remaja dikatakan memiliki subjective well being yang tinggi apabila memenuhi tiga aspek yaitu memiliki kepuasan hidup yang ditandai dengan kegiatan yang positif seperti olahraga, tidak merokok, pola makan yang sehat, tidak menggunakan alkohol dan obat-obatan, ekstravert (terbuka), terdapat perasaan optimis, memiliki locus of control internal dan memiliki self efficacy dan self reliance. Selain itu, mereka juga jarang mengalami afek negatif seperti kecemasan, kemarahan, ketakutan, rasa malu, sedih, marah, kecewa dan depresi. Ciri yang lain adalah seringnya mengalami emosi positif berupa sering merasakan kesenangan, enjoy, bangga, aktif dalam kegiatan yang positif. Hasil penelitian Zullig \& Frisch (dalam Nisfiannor dkk, 2004) menyimpulkan bahwasanya kepuasan hidup yang tinggi pada remaja juga berhubungan dengan kesehatan fisik, tingkah laku dan pola makan yang sehat.

\section{KESIMPULAN}

Berdasarkan hasil analisis, dapat dinyatakan bahwa tidak ada hubungan antara perilaku makan dan tingkat subjective well being. Perilaku makan adalah bagian dari kesehatan. Namun, kesehatan tidak hanya dipengaruhi oleh perilaku makan, namun terdapat beberapa faktor yang justru lebih berpengaruh yaitu pola pikiran, emosi, dan pola perilaku. Dengan demikian hal ini menjadi salah satu alasan mengapa pola makan tidak mempengaruhi tingkat subjective well being.

Berdasarkan pembahasan di atas, dapat dinyatakan bahwa rekomendasi yang dapat disampaikan adalah beberapa hal yang dapat diperhatikan terkait dengan kebahagiaan adalah tidak hanya masalah perilaku makan namun juga terkait dengan pola pikiran, emosi, dan pola perilaku.

\section{DAFTAR PUSTAKA}

Ariati, Jati. 2010. Subjective well being (kesejahteraan subjektif) dan kepuasan kerja pada staf pengajar (dosen) di lingkungan fakultas psikologi universitas diponegoro. Jurnal psikologi Undip. Vol 8, No 2.

Cha, Kyeong-Ho. 2003. Subjective well being among college sttudents. Social indicator research. Vol 62-63. No 1-3. Page 455-477 
Diener, E., Larsen, R. J., \& Emmons, R. A. (1985). Person situation interactions: choice of situations and congruence response models. Journal of Personality and Social Psychology, $47,580-592$.

Diener, E., Oishi, S., Lucas, R.E., \& Suh, E.M. (1999). Cross cultural variations in predictors of life satisfaction; Perspective from needs and values. Personality and Social Psychology Bulletin , 25, 980-990.

Diener, Ed. 2000. Subjective well being. The science of happiness and a proposal for national index. American Psychologist Association. Vol 55, No 1, 34-43

Diener, Ed. 2003. Subjective well being is desirable, but not the sumum bonum. USA: Paper on workshop on subjective well being.

Diener, Ed. 2008. Assesing well-being. Collected works of Ed Diener. New York: Springer.

Eid, Michael., \& Larsen, Randy, J. 2008. The science of subjective well being. London: The Guilford Press.

Ehrlich, Scott, Brian dan Isaacowitz, M. Derek. 2002. Does subjective well being increase with age? Perspectives in psychology. P. 20-26

Fuglestad, P. T., Bruening, M., Graham, D. J., Eisenberg, M. E., \& Neumark-Sztainer, D. (2013). The associations of eating-related attitudinal balance with psychological well-being and eating behaviors. Journal of Social and Clinical Psychology, 32(10), 1040-1060.

Gibney, et al. 2009. Gizi Kesehatan Masyarakat. EGC. Jakarta

Hoorn, Van Andre. 2007. A short introduction to subjective well-being: It's measurement, correlates, and policy uses. Radboud University Nijmegen: Nijmegen Centre of Economic.

Jiang, Wang; Qingyue, Meng; Yip, Winnie; Qiang, Sun; Jiangbin, Qu; Liying, Jia. 2010. Impacts of social and demographic factors on residents' subjective well-being in rural China. Chinese Journal of Population, Resources and Environment. Vol.8 No.1

Khumaidi, 1994. Gizi Masyarakat. Penerbit PT. BPK Gunung Mulia. Jakarta

Larsen, J. Randy dan Eid Michael. 2008. Ed Diener and the science of subjective well being. Guilford Publication

Michalos, Alex. C. 2007. Education, happiness and wellbeing. Canada: University of Northern British Columbia

Muhibullah. Ahmad. 2011. Peranan mahasiswa dan pergerakan mahasiswa. Diakses tanggal 6 Desember 2012 dari http://087828150515.blogspot.com/2011/09/peranan-mahasiswa-danpergerakan.html

Nisfiannor, M., Rostiana, \& Puspasari, T. (2004). Hubungan Antara Komitmen Beragama dan Subjective Well Being Pada Remaja Akhir Di Universitas Tarumanagara. Jurnal Psikologi , (2), 1. Jakarta: Universitas Tarumanegara.

Prasetiyo \& Andriani. 2011. Hubungan antara kecerdasan emosi dengan subjective well being pada mahasiswa tingkat pertama. Proceeding PESAT (Psikologi, Ekonomi, Sastra, Arsitektur \& Sipil). Vol 4. Hal 22-26 
Putri, Mardha Tresnowati \& Sutarmanto, Hadi. 2009. Kesejahteraan subjektif waria pekerja seks komersial (PSK). Psikodinamika. Vol 2. No 2

Qonitatin, Novi. 2010. Depresi pada mahasiswa. Diakses tanggal 13 November 2012 dari http://staff.undip.ac.id/psikologi/novi_qonitatin/2010/07/20/depresi-pada-mahasiswa/.

Schimmack. 2006. Internal and external determinants of subjective well being: Review and policy implication.

Sudjarwadi. 2003. Ramai-ramai menggodok calon pemimpin. Diakses tanggal 20 Juli 2012 tanggal http://www.shnews.co/duniakampus/uki/detile-452-ramairamai-menggodok-calonpemimpin.html.

Suharjana. 2012. Kebiasaan berprilaku hdup sehat dan nilai-nilai pendidikan karakter. Jurnal pendidikan karakter. No. 2.

Tellegen, Auke \& Lykken, David. 1996. Happiness is a stochastic phenomenon. Psychological science, Vol 7, No 3

Tran van Thanh. 1986. Family, community-related factors and subjective well being among vietnamese refugees

Utami, Muhana. S. 2009. Keterlibatan dalam kegiatan dan subjektif well being mahasiswa. Jurnal psikologi. Vol 36 No 2 hal 144-163

Watson, Clark, \& Tellegen. 1988. Development and validation of brief measures of positive and negative affect: The PANAS scales. Journal of personality and social psychology, 54 (6) 1063-1070.

Wirawan, Henny, E. 2010. Kebahagiaan menurut dewasa muda Indonesia. Universitas Taruma Negara 